\title{
Promise Okekwe: Rising Star on the Nigerian Literary Horizon
}

\author{
Ijeoma C. Nwajiaku*
}

\begin{abstract}
Literature in imitating reality has remained a dominant instrument for investigating the complexities of human life and human condition in general. In the hands of African female writers it acquires added significance to become an almost indispensable tool for focusing on the location, consciousness and reality of the female in her society. It is from such a perspective that this study will examine selected works by Promise Okekwe, a young and upcoming talent on the Nigeria literary horizon. Okekwe was first published in 1992. A resilient and dynamic writer, she has continued to produce texts at a pace akin to Buchi Emecheta's. Her works reveal a remarkable understanding of the human mind. She thus aims at a reconstruction of the wider society. Indeed her texts validate Okonjo Ogunyemi's assertion that African female writers are preoccupied with more than just the fate of women; they are currently interested in the effects of diverse forms of oppression and on the fate of men, women and children, communities and nations, in a continent that has been raped and remains disoriented from continued sacking and pillaging by rapacious people and their underlings (Africa Wo/Man Palava, 1996). This study will thus focus on Okekwe's first collection of short stories, Soul Journey into the Night as well as the novels, Deep Blue Woman and Hall of Memories. It will seek to uncover the writer's insightful foray into the diverse ailing sectors of her society and further attempt to locate her works within the framework of the female writing tradition in Nigeria and Africa.
\end{abstract}

http://dx.doi.org/10.4314/ujah.v13i2.7 


\section{Introduction}

Doubtless the Nigerian literary horizon, by the end of the twentieth century, was appreciably characterized by vital transformational evolutions, transformations that have been as far reaching in their inclusive embrace as they have been in the ensuing controversy generated. One realizes too that the works of the much younger writers suggest perhaps a contrived venture to deviate from the already recognizable trends in African writing. Expectedly, this departure from established pattern has left scholars and critics wondering if the scene has indeed witnessed the birth of yet another generation of writers. The fact is that they are faced with new circumstances, new situation, new technologies; you know that the poet is now living in a different world from the so-called previous or older generation ... you will discover that the way we respond to an event will be different ... Erazua Oniha. ${ }^{1}$ For Chuks Ohai ${ }^{2}$ new Nigerian writing actually is a kind of writing that gives beyond sologananeering. It is a new kind of writing that mirrors contemporary Nigerian society, presents salient issues with a view to charting out courses of renewal for society, This concern is examined by Uduma Kalu in a Guardian online article titled "Harvard Scholars Brainstorm on New Nigerian Writing." 3 Kalu rightly observes that in most literary circles in Nigeria today, "the question that is frequently asked is whether there is really a new generation of Nigerian writers?" (1). In his words,

Whereas many writers such as Obi Nwakanma, Nduka Otiono, Toyin Adewale and others who say they constitute a new generation of writers, otherwise referred to as the third generation of Nigerian writers, other writers, mostly those in the first and second generation group say there is no shift yet in the practice of the literature to say there is new generation (1). 
Listed among those who insist on the absence of a new generation of writers is Prof. Tanure Ojaide, himself a poet and a professor of creative writing. Again Uduma Kalu records Ojaide's summations,

... May be another five years, somebody will talk about a new generation ... The new ones, they have not really fully come out. They are still forming. It's like a foetus which is not fully formed ... But when you look at literature, I think each generation tries to go against the older generation ... Myself and people like Niyi Osundare we studied Clark, Okigbo, Soyinka ... we loved them. We respect them. But we don't want to write like them. So it was something like deliberate ... it's like you want to take a different direction ... I cannot tell of the present, the new group ... (1-2).

Ojaide's opinion has been quoted extensively as this would enable us to either validate or contradict this thought within the course of our study. For, as Uduma Kalu concludes, a combination of factors such as Ojaide's view-point as well as the apparent difficulty in locating differences between the works of the newer generation and the older (represented by Ofeimun, Osundare, Ojaide, Nwankwo, Enekwe, Iyayi and so on) still leaves the people unable to decipher what accounts for the distinctiveness of the newest generation.

Speaking then of the new generation of Nigerian writers, this paper focuses specifically on Promise Ogochukwu Okekwe, a female writer, and unmistakably a dynamic, piercing and courageously insistent voice within the group. Born in the sixties in Enugu, in South Eastern Nigeria, Okekwe, formerly Onwudiwe, received basic primary education in Onitsha, also in Eastern Nigeria. Later she 
obtained a Bachelor of Arts in English \& Literary Studies from the University of Calabar, and an M.A and Ph.D. from the University of Ibadan. Married and presently living in Lagos with her family, Okekwe works with Liberty Bank Plc., also in Lagos, as Head of Cooperate Affairs.

An incredible female of many parts, Okekwe's versatility is best appreciated when one considers her ever increasing volumes. As much a poet as a novelist, she has equally published collections of short stories and numerous children's tales. Included among her six collections of poetry are Canals in Paradox and My Mother's Eyes Speak Volumes. Her over ten published children's titles include Tales by Heaven's Gate, Sweet Kasara, Drums and the Dancing Beggar, and The Secrets of the Palm Kernel. Indeed Okekwe also has to her credit a drama text entitled Afulenu.

Her collections of short-stories include Soul Journey into the Night (1992) and House of Chaos, while the list of novels houses such titles as Deep Blue Woman (1999), Good Night My Love (1996), and Hall of Memories (2001) amidst several others. Interestingly Okekwe has sometimes written under the pseudonym Ada Iloekunanwa, to produce such texts as The Surveyor of Dreams and The Street Beggars as well as some children's stories. Our study of Okekwe's works in this paper will focus however on a selection of her works of prose.

\section{The Not So Silent Female(s)}

Evidently, one cannot afford to ignore Okekwe and her female contemporaries. This claim is ratified by Uduma Kalu's mention of Toyin Adewale among the new generation of Nigerian writers, an act that is as gratifying as it is significant; gratifying because it does indicate the possibility of finally naming female writers among their contemporaries. Significant because, even within the same write-up, each time names representing first and second generation writers are mentioned, the names of older female writers are blatantly disregarded; a 
pity indeed, considering that this is a 2001 article. Even more regrettable perhaps is the obvious fact that the Harvard Scholars Brainstorming Session held to deliberate on new Nigerian writing did not represent the view of any Nigerian female writer. At least going by Uduma Kalu's article, we note also that Harvard University "decided to wade into this argument by hosting three new Nigerian writers" (2). Thus Maik Nwosu, Obi Nwakanma and Akin Adesokan (all males), were privileged to represent the new voices.

We pause then to wonder at the proclivity to relegate African female writers perennially. A clearly unfavourable disposition which has elicited much criticism from scholars and critics (particularly females), over the years, as they seek to redress the anomaly. Chikwenye Okonjo Ogunyemi (1996), observes how "African women go unseen, unheard, and unheeded, since novels written by them and about them are still generally ignored by readers and critics" (1). Chioma Opara (1999), insists that "while male writers especially of the generation were enjoying copious attention, female writers were distinctly beyond the pale of serious criticism" (1). Perhaps this dismal climate eclipsing the arena of women's writing also accounts for Toyin Adewale's mournful lament in her introduction to Breaking the Silence (1996):

I find it sad and ironic that more than thirty years after Flora Nwapa published Efuru, an anthology of short stories by Nigerian women writers must carry the title, Breaking the Silence. Where are the voices of Nigerian women writers? (vii).

Incredible as it may sound, one realizes upon a deeper search that African and particularly Nigerian female writers have not really been silent. The simple fact of their ostensible 'silence,' stems from the paucity of attention accorded them. 
Florence Stratton (1994), makes a comparable observation when she remarks that Ngugi's periodization of contemporary African Literature was based on men's writing and therefore worked to "exclude women's literary expression as part of African literature" (9).

Furthermore, Toyin Adewale is unable to hide her discomfiture at the perhaps (not) designed exclusion of female writers from the all-male literary canon. For she again reiterates, 'I vividly remember taking a final year course in Nigerian literature as a university undergraduate in which I studied ten books, spanning prose, poetry and drama, all by male writers' (vii).

We dare to enthuse however that though gradual, slight changes are being discerned on the Nigerian literary horizon. Hardly surprising, when one recognizes the aggressive vigour with which the recent crop of female writers forged onto the scene. Their determined thrust is as unwavering as it is unrelenting. In addition, the now increasing number of Nigerian female scholars and critics poised to study the works of female writers is doubtless encouraging. For, indeed, the fate of a writer is most often dependent on the work of the critic.

\section{Okekwe's Short Stories}

We return now to Okekwe's texts. Perhaps a good reading of her work should commence with an exploration of her first published text Soul Journey into the Night, which appeared in 1992. What this remarkable writer does in this collection of eleven short stories is note-worthy. The story titled "The Sons of Yamanata" deplores the African woman's unrelenting quest for the immeasurable joys which children are presumed to bring to a mother. Somewhat reminiscent of Emecheta's Joys of Motherhood, Yamanata's nine sons unleash great havoc in their own lives and in the lives of their parents, thereby bringing Yamanata and her husband intense misery and 
anguish. The son named Ben, who appears different, suddenly goes berserk on the eve of his degree examination. As Ben is confined to a mental asylum, his father dies of heartache and a broken spirit.

Superimposed on this story, however, is Okekwe's investigation of some cultural beliefs which are prevalent in her society. Yamanata, who is confounded by the mysterious calamities engulfing her family, visits a 'native doctor' to seek solutions to the problems. Ironically the man, who proffers neither explanation nor remedy, merely aggravates her despondency through his startling revelations. As Yamanata's sons, one after the other either drop out of school or disappear into unknown destinations or get poisoned or get addicted to hard drugs, or burgle their parents' home, or swindle them of their money or even just "walked into darkness with careless abandon" (28), the reader is left to wonder at this conundrum. It is revealed that her family is labouring under a generational curse, for her great-grand father had incestuously begot a son by his daughter. Yamanata must thus pay the price as all her sons will be sacrificially destroyed.

Okekwe's style in this text is peculiar for she relentlessly pursues the story of Yamanata in the two stories that follow titled "Mystery of Dawn" and "Yamanata" respectively. These tales which appear as sequels to the first, show that Yamanata's friend travels to Nigeria to rescue her mentally deranged son Ben from the asylum; he recovers under her care and love and eventually gets married, only to father the reincarnated Yamanata. Again Okekwe looks at another perplexing belief amongst African people -that of reincarnation.

Perhaps the ability to incorporate so many complex issues into her work is one of the distinguishing characteristics of this young writer. Her style in the first story reminds one of Mariama Ba's So Long a Letter. Okekwe also adopts a similar pattern of a female unburdening her heart to another female, 
first through a letter and later, in a diary form. As one reads these very private details of her life which Yamanata records in her diary, (with the hope that her friend Oyinene would someday read them), one appreciates the magnitude of love, trust and confidence that had existed between these women. The fact that Oyinene does not disappoint her late friend's unvoiced expectations, subscribes to the womanist call for female bonding.

Unlike Emecheta's however, Okekwe's story does not paint a completely bleak picture of motherhood expectations, for juxtaposed within the same story is that of Oyinene whose only child turns out to be a perfectly rewarding son. Of significance in the story also is the fact that Yamanata found much solace in her wonderful relationship with her beloved husband. Oyinene too enjoys a good marriage. This demonstrates that Okekwe's staunch belief in the possibility of positively enduring relationships (marital or otherwise), between African men and women comes across powerfully in her texts. Again this upholds an aspect of the ideological stance of African womanism, which desires the African female's peaceful coexistence with the male either as husband, father, brother, uncle, friend or whatever, and work together to engender cultural and societal advancement.

One further notes the streak of optimism in Okekwe. This too is often an integral part of her work. Thus after Yamanata's tragedy in the first story, the next, titled "The Mystery of Dawn" shows that at least one of the sons is redeemed. A combination of love, care and many prayers ensure divine intervention, for God responds to Oyinene's prayers.

If Promise Okekwe appears to have paid tribute to her predecessors through the similarities noted earlier, her irrepressible efforts to stamp out a vividly distinctive style cannot be disputed. She is as courageous as she is daring, often exhibiting an amazing capability to grapple with complex 
contemporary issues. This crucial point brings us to what could perhaps be summed up as the overriding concern of this talented writer.

Evidently Okekwe is highly preoccupied with issues of bad governance, societal decline, diverse forms of oppression and injustice, the moral decadence engulfing the nation and related matters. Thus we see such themes running through much of her work. The directness and determination with which she pursues her subject matter leave one in little doubt that this is a writer with a purpose. A point Chikwenye Okonjo Ogunyemi makes about African female writers in her landmark work Africa Wo/Man Palava (1996), 'As writers with a cause, women are playing the transformational role of the griotte as entertainer, teacher, social critic, ideologue, and wise but despised mother' (3).

In the stories titled "Songs of the Lunatic," and "Politics of the Lunatic," (in Soul Journey into the Night), Okekwe makes an impressive incursion into virtually every facet of the Nigerian society. She sheds light on the innumerable atrocities entrenched within it. What makes these tales extraordinary is that a reader is made to listen to a completely nude and mad man. Mad as he is, he merely rambles on and on and leaves in the blazing trail of his tirade an astounding exposition of our malaised society. Blunt and challenging, the poignancy of his words leaves an astonished and embarrassed reader wondering as to the insanity of the 'lunatic' turned social commentator.

What a critic he turns out to be! Nothing escapes his overly sharp intellect. The 'intelligent madman' as he calls himself had worked as an accountant before overwhelming situational pressures induce lunacy. Since his malady is an empirical outcome of the nation's asphyxiating atmosphere, one is forced to recognize a society that harbours the potential to maim, incapacitate or destroy its citizenry; a frightfully distressing trend that requires at the least, dire attention. Of 
course, the other numerous issues he vociferously raises can hardly be ignored. For he whips at matters of bad governance, incessant workers' strikes, collapsing education standards, relentless power failure, acute fuel scarcity, inadequate salaries, the venal civil service, general moral decadence in society and all such vices.

Especially worthy of note in Okekwe's fiction is the topicality of her themes. Thus the story titled "Soul Journey into the Night," examines the worrisome issue of swindling people, which is more popularly dubbed '419,' in her nation, while " The Blind Woman and I," explores the depravity of the human mind. In this latter title, a blind old woman deliberately exploits people who sincerely attempt to assist her on account of her age and blindness. Heartlessly taking advantage of their kindness, she cunningly gets them to spend money on her endless needs. Simultaneously denouncing such wrong and deplorable attitudes, the writer insists that "the fault is in the system that pushes us to various vicious acts" (Soul Journey into the Night: 132).

\section{The Society, Decadence and Okekwe's Novels}

Perhaps Deep Blue Woman (1999) stands out as one of this writer's most remarkable texts. A work of discernible ingenuity, and coming several years after the first (though she has several in between), this novel announces Okekwe's rapid maturity as a literary artist. A text of considerable volume, the complexity of the multifarious issues tackled is re-echoed in its collaborating plot. Set in a country named Ashamza (her fictive name for Nigeria), the narrative revolves around the life of Elina, a truly exceptional woman. Parallel to her story however and rendered in the veracious Okekwe style, is an indepth analysis of the Ashamza nation. The interconnectedness between these two dissimilar entities is both intriguing and horrifying, for enmeshed within Elina's story is the turpitude that depicts the nation Ashamza. 
On a trip back to Jadara, the nation's capital and also her fictive name for Lagos, Elina the heroine in this novel has a most unnerving encounter with two university graduates at the local motor park. Both young men labour in the park to eke out daily livelihood, one working as a taxi driver and the other as a motor park tout or "bus conductor" locally referred to as 'agbero.' Deeply shaken by their plight, Elina secures them employment at her place of work. While Okey does well at his job, Martin is fraudulent and embezzles funds, until he is relieved of his job. As a reward for her kindness to him, Martin rapes Elina, kills her boyfriend and the old security man before fleeing the country to Asia. There he amasses a fortune and returns to Ashamza two decades later to a hero's welcome and to become a member of the ruling class.

Okey and Martin's pitiable situations afford the writer an opportunity to examine the country's increasing rate of unemployment among its youths. A situation which reduces university graduates to 'agberos' calls for some reform. Yet there is the subtle hint that any work however demeaning is a better option to involvement in crimes. For Martin however, the relief of having a job does not seem to cure his inherent vileness. Elina notices how he "liked to talk shop, dress and act rich" (79), indeed a fast growing trend among present day Nigerians. She is thus sad to realize,

Less than a year of getting a job and finding the possible relief for himself and his family he was already thinking of siphoning people's money for his own personal use. He had already involved himself in duplicity and artifice (79).

It is evident in the novel that crime has taken on some added dimension and acquired a distinct sophistication in Ashamza. Clearly, it is no longer an era in which only illiterate jobless men are associated with certain kinds of nefarious acts. 
Thus Tiko Lexus, who lived and studied abroad returns to his country to become a paid assassin hired by the "rich and mighty" to "eliminate their enemies" (27). A perfect gentleman to an onlooker, who would ever link him to a crime? Even his mother Elina, is deceived, as she is completely taken in by his ruse. Ironically, there is the suggestion that innate evil traits could be hereditary. Thus evil passes on from one generation to another, for Tiko is Martin's son, and the result of his rape of Elina. Like his father therefore, Tiko had wealth, power and women, yet making money remained an obsession for him, what more did he want? Why did he pursue money, power and women with an insatiable appetite ...? Even Tiko himself could not put a finger to the source of this immoral compulsion. But one thing he was certain of was his age-long ambition to rank among the three richest men in the world and certainly the richest man in his country. It was an ambition he began to nurse from childhood ... (179).

To a large extent also, some ills of our modern society, have been attributed to the negative impact of aspects of western 'civilization' on the nation. For instance, the depiction of Martin's sexual assault on Elina reeks of a scene from a western movie. From his undetected removal of Elina's house key from her handbag in the office, to his successful procurement of a duplicate, to the ease and confident arrogance with which he effects his incongruous plot, to his subsequent elimination of the old man testifying against him and to his immediate escape to another country, one cannot but appreciate the complexity and advancement of Martin's mind, deplorable as it is.

Yet it is this same run-away criminal that returns to the country an extremely wealthy and much-sought after celebrity. Predictably, the nation's television authority features his return referring to him as "an illustrious son of the soil" (168). Shortly afterwards, he "embarked on an expensive campaign 
and won a landslide victory" in an election, (171). As the writer notes,

... Everybody wondered who voted him in but they did not wonder for too long because it was clear that his money did. And a lot of people were on the side of money. They were so impoverished that they could not but take whatever money that was given to them, at least to buy food to remain alive (171).

The reader is possibly disgusted therefore, but not amazed to witness this manner of selection and appointment of unqualified persons into sensitive positions of leadership in this nation. Matilda accurately foretells her appointment as commissioner and even asks Elina if "she would not mind being a commissioner or something" (165). The point is that Anita her friend, is well known to Martin's wife who in turn is "a distant cousin of the head of state of Ashamaza" (165). Okekwe ridicules and decries a situation in which governance is left in the hands of pernicious individuals, who frolic with the destiny of a nation and jeopardize the lives of its masses.

Hardly anyone escapes the glare of Okekwe's scrutiny, for she does not cower before issues, however intimidating they appear, and in spite of the caliber of persons involved. Thus we read about the unnamed General (perhaps the head of state), who illegally fathers three children from three different women; this aside from his well-known love relationship with Matilda. As duplicitous in his love affairs as he is fraudulent in governance, he brazenly awards contracts worth huge sums to his female lover. On her advice, he relieves three service chiefs of their duties, for "he was too much in love to delay his decision" (23). This heightening disregard for moral ethics by leaders and their perpetual entanglement in scandalous and well publicized licentious debauchery is clearly a matter that 
calls for attention in contemporary society. Okekwe returns to these issues more extensively in her Hall of Memories (2001). If the important and highly placed men within the society bear the brunt of Okekwe's fury for their role in fostering moral decadence, the women are not allowed to escape either. Anita therefore becomes a symbolic representation of the typical female 'go getter'. Although already wealthy having inherited her parents' fortune, "her rich friends also gave her more" (165), this in addition to what her business deals continue to rake in. Anita is nonetheless unprincipled, described as "lewd", "rude and callous" (164), she sleeps around with whichever man momentarily catches her fancy.

A thoroughly depraved female she neither shows interest in a lasting relationship with any man, nor does she desire to be married at all. Indeed Anita says to a wife who traces her husband to her house: "I just want to know what it is that you people die for in these men. In fact, I have finished with your husband, if you can, please take him away he is littering my bed" (164). As bold as she is daring, we read too that she would bump into someone's husband and ask him why he was staring at her displayed nipples. She always dressed licentiously and felt no qualms about being caught by wives whose husbands she slept with (164).

While this depiction of Anita's personality could be read as an indictment of the overly emancipated woman (product of euro feminism perhaps), who has lost every sense of the African moral values and is bent on wreaking havoc on society, one could also interpret it as a reversal of roles. Suddenly the woman has come of age, has obtained her independence and is currently acting out a script written by the man. Perhaps this view point was earlier expressed by Okekwe in "Yamanata" when one reads,

Men were always having mistresses, girlfriends and concubines ... they did not really penalize 
them for such ... But the women who did similar things soon became notorious for they were abused and castigated. Men were always going into brothels, but women who were seen around there were called prostitutes, whores and sex workers, (55).

With Matilda, Okekwe shows again that women are primarily human-beings. Thus one encounters in Matilda's nature the acquisitive and insatiable kind of greed often associated with males. She owns a Jaguar, a Pontiac, a Cadillac and a Mercedes; as the reader is told, "she did not want the world to pass her by" (163). Indeed she desires to own the best clothes in the world and craves attention, compliments and publicity. Further one discovers how she loves to garner riches too. Nothing is ever enough for her. The houses her husband has built and put her in charge of are not enough. The shops and boutiques he opens for her always have something missing in them which she would complain about until she adds it. (163).

Okekwe like her contemporaries does not attempt to gloss over the role of women in modern society. If men have done much to endanger societal advancement, so have women, the call then for reformation includes everyone, so the writer seems to be saying.

Despite her involved commitment to multiple issues of national interest, Okekwe does not thrust aside major concerns that may be deemed peculiar to the female in her society. Rather, she introduces in her writing ideas that are refreshingly different even if sometimes controversial. In Deep Blue Woman for instance, Elina appears to be the lone surviving child of her late father Oluoha, after her sister eloped with a man. In his lifetime Oluoha had refused to yield to the pressure of marrying a second wife, when his beloved wife Urenma failed to give birth to the eternally desired sons, Okekwe 
choses to present a rather enviable picture of Oluoha and his wife in a most romantic relationship. Apparently their inability to have a son makes little difference to their obviously fulfilled lives, and delight in each other.

The reader is therefore surprised to witness a ragefilled Udelu (Oluoha's half-brother), storm into Oluoha's compound, and aim a gun-shot at the unsuspecting Oluoha. As we are informed "he felt righteously aggrieved" since he considers "Oluoha's negation of his advice and his blunt refusal to conform to convention" to be a "calculated insult on his person" (47). Although Oluoha does not die, the resultant confusion triggers off an unprecedented chain of counter reactions which result in the death of Udelu himself and more tragically in that of Urenma, Oluoha's wife. The depiction of this most unusual and somewhat bizarre scene affords Okekwe an avenue to thoroughly castigate the ridiculous extent to which the absence of a male child could drive people in this culture. The matter becomes more pronounced in this case, because Udelu is not even directly affected.

Perhaps the more significant of Okekwe's considerable achievements in this narrative revolves around her enthusiastic restoration of Elina's homestead to her. In this culture again, it is unheard of for a female child to dare to suggest the possession of her late father's inheritance, even when she is an only child. Thus Oluoha's compound is allotted to strangers, as he has no sons. Contrary to expectations, Elina suddenly appears and demands to have the occupants evacuated so she can settle in and rebuild the now falling apart premises. This was a development clearly unheard of in the town. (Incidentally, Akachi Adimora Ezeigbo later deals with a similar issue of denying females the right to have a say in their late father's assets where there is no son in the family in The Children of the Eagle).

All efforts to dissuade Elina from her self-set goals fail. The elders of the town condescendingly attempt to disregard 
her request and attempt rather to talk her out of her ignorance. Neither ploy works. A trying and protracted battle follows. Elina threatens to go to court and they quickly restore her father's possessions to her. True to her word, Elina does build a small modern house on the land and continues to visit the village, thereby familiarizing herself again with her people and their culture. Providence seems to honour her efforts, for her son Tiko Lexus eventually would inherit the compound.

One readily discerns the author's symbolic and thorough dismantling of negative and limiting images of the female in this society. She suggests then that emphasis should be more on having well-brought up children who are capable of living noteworthy lives irrespective of gender. For indeed no male child could have done better than Elina. In contrast however, her sister merely disappears to pursue the pleasures of her heart, like the sons of Yamanata; therefore, she too is no good to her parents.

Elina's commendable takeover of her father's homestead does have several other implications for the womanist ideology currently sweeping across the continent of Africa. For one thing it re-emphasizes the creditable roles women could play if subjugating chauvinistic attitudes and policies would only afford them the greatly craved opportunities. It also suggests that where peaceful dialogue and negotiations fail, women must be prepared to apply some civilized force to insist on their rights. For it is only when Elina threatens to go to court after eight exasperating months of failed negotiation that the men listen to her.

There is also a call to women to intervene in the affairs of the nation. Thus the pregnant women in an antenatal clinic spontaneously stage a protest as the news of "a bomblast in Atundo's residence" reaches them. Believed to be masterminded by Atundo's political opponent, the bomb kills his wife and three children. Enraged at the turn of political activities in the nation, the women bearing in their wombs as it 
were the future generation of the country unanimously give vent to their feelings of anguish. Thus:

The pregnant women were now screaming at the top of their voices. As soon as one of them got up and began to walk about in anger, the others joined and a protest began. The militant song ignited their hearts and they howled and howled. (145)

Although some of the women accurately predict that nothing would come out of their demonstration, as the major suspect Chief Zena is apparently above the law, yet Okekwe perceives the voiced complaint as a better option to keeping mute in the face of the hideous atrocities being witnessed daily. At least some newspaper reports and television broadcasts present the opinion of the womenfolk, just as they, (i.e. the media), transmit the reaction of the minister for internal affairs. Again the author in her characteristic confrontational boldness records:

... the minister for internal affairs who spoke about the incident lambasted everyone who had ever said anything against Chief Zena. He ordered "the disgruntled elements" to desist forthwith from detaining Chief Zena. Everybody shuddered. But that was not strange. Ashamza was full of lawmakers. Just like it was replete with lawbreakers. If it had lawkeepers, that would be novel... Instead most of its lawbreakers were the sanctimonious lawmakers. And they were the ones who broke the law with impunity ... (146). 
In spite of the above and numerous other bleak images of the decaying society, one is greatly encouraged by the author's irrepressible and infectious optimism. She appears to be a firm believer in a restored future for her nation. She clearly eschews complacency, resignation or acceptance of the present situation. Rather, each individual is actively enjoined to participate in the reordering, restructuring, and rebuilding of the collapsing system. Elina, despite her pregnant state, alights from her vehicle to lecture a bribe collecting policeman, on how his negative conduct "destroys the image of the country" (121).

Okekwe repeatedly adopts this sermonizing approach as a strategy in her works, as it affords the authorial voice a chance to express an opinion; sometimes, though this does not play out so well. In such instances, the issue being discussed appears overly stretched and the point overlaboured, thereby tasking the patience of the reader.

\section{Conclusion: Call for a New Social Order}

One can hardly deny that Promise Okekwe is a writer of repute in Nigeria. That she is yet to earn the recognition she so richly deserves outside her home base is a direct consequence of the effect of the nation's collapsed economy on the fate of the publishing industry. In more recent years, multinational publishing firms that have the distribution network to circulate publications within and beyond the country have had their activities crippled. The hitherto springing up indigenous publishers have also been as adversely affected. Clearly, these unfavourable developments have left new writers grossly disadvantaged. The few writers who are able to get published must either fund the publication of their works, resort to selfpublishing, or remain at the mercy of exploitative publishers.

While Okekwe is fortunate to own a publishing firm which publishes her works and those of other writers, particularly women, one sees this trend again as having an 
obtrusive effect on the quality of new writing in Nigeria. Many new texts are currently replete with spelling errors, grammatical mistakes and mixed up tenses. Visibly a result of inadequate and inappropriate editing. Evidently, these factors pose some challenges to the future of the bourgeoning literary field in the country. Also, it becomes a problem that must be rectified to forestall the damaging effect that such mistakes might have on the grammar of the youth of the nation.

Besides this distracting quality, we recognize in Okekwe an indisputable talent, who is as versatile as she is proficient. That she has proved her mettle in different literary genres is validated by the awards she has won for her works of prose and poetry. She has equally worked on a trilogy; the first is titled Hall of Memories while Zita-Zita and Fumes and Cymbals are the names of the second and third volumes respectively. Okekwe is also putting finishing touches to a seven hundred and twenty page miscellany which she claims to have been working on for about a decade now. Titled Women from the Crystal Deep, this writer hopes to launch this as soon as it is completed. Presently in Germany for a three month stay, she is working on some forthcoming titles.

We see then in this young and forceful female, a voice that must be reckoned with. Insisting that she is neither feminist nor womanist, Okekwe declares that she is basically a writer who is tormented by the sorry state of her nation. She is undeniably courageous, often times confrontational or soliciting and at other times defiant. In her works she often makes an insightful probe into the culture of her people and attempts to find a meeting point between that and modernity. Sometimes she adopts an arguable stance as in her story "The Wind's Laughter", where Ada and Ego make up their minds after their initial pains to live happily and share a husband.

It is also a feat that Okekwe goes beyond mere identification of societal difficulties. Often she proffers solutions. Thus in "Sandstorm", her protagonist an avowed 
believer in the equality of all human beings parts ways with her family in order to marry her 'Osu' (out-caste) lover. And in "Another Dawn" which is an unprecedented exploration of the 'alaiye boys' menace in Lagos, Okekwe through Paana succeeds in using the police to gather the miscreants into a camp. There Paana is to "counsel the errant ones on THE NEED FOR THE ESTABLISHMENT OF A NEW WORLD ORDER" (192). Perhaps no other words serve as a better summary of Okekwe's mission on the Nigerian literary scene. Just as the havoc-causing 'area boys' are removed from the streets, so too is Martins eliminated in Deep Blue Woman and Tiko at the end of the novel hands himself over to the police. In Hall of Memories too, the despicable Head of State dies. The deaths of these representational symbols of moral decadence are contrasted in Deep Blue Woman by the birth of twin babies and in Hall of Memories by the survival of ZitaZita's baby. In these young and innocent ones reside the writer's unwavering hope for a bright future for the country.

In her more than a decade of writing therefore, Okekwe has distinctly established herself as a writer of immense worth. As troubled by the state of her society as by that of the female, Okewe's thematic concerns and unique style reinforce the emergence of a new generation of Nigerian female writers. Her veracity is appealing as is her artistic manipulation of materials. On the whole Okekwe is, as her name pledges a most 'promising' figure on the contemporary Nigerian literary scene.

*Ijeoma C. Nwajiaku is a lecturer in the Department of Languages, Federal Polytechnic, Oko Nigeria. 


\section{Notes:}

1. Erazua Oniha, a Nigerian poet is quoted by Uduma kalu in "Harvard Scholars Brainstorm on New Nigerian Writing," an article in The Guardian Online, Monday, April 2, 2001.

2. Chuks Ohai, a Nigerian short story writer is equally quoted in the same article above.

3. See ibid.

\section{References}

Acholonu Catherine O. Motherism: The Afrocentric Alternative to Feminism. Owerri: Afa Publications, 1995.

Adewale Toyin and Omowunmi Segun, (Eds.) Breaking the Silence - An Anthology of Short Stories. Lagos: Writa, 1998.

Adebayo Aduke, (Ed.) Feminism and Black Women's Creative Writing- Theory, Practice, \& Criticism. Ibadan: AMD Publishers, 1996.

Boyce, Davies C., \& Adams Graves A., (Eds.) Ngambika: Studies of Women in African Literature. Trenton: Africa World Press. (1986) 1990.

Chukukere, Gloria. Gender Voices \& Choices: Redefining Women in Contemporary African Fiction. Enugu: Fourth Dimension, 1995.

Egejuru Phanuel A \& Ketu Katrak, (Eds.) Nwanyibu: Womanbeing and African Literature. Trenton: Africa World Press, 1997.

Kalu Uduma. "Harvard Scholars Brainstorm on New Nigerian Writing." The Guardian Online. www.guardiannewsngr.com Monday, April 2, 2001.

Kolawole Mary Modupe. Womanism and African Consciousness. New Jersey: Africa World Press, Inc., 1997. 
Okekwe, Promise. Soul Journey into the Night. Lagos: Oracle Books, (1992) 2001.

Okekwe, Promise Deep Blue Woman. Lagos: Oracle Books, 1999.

Okekwe, Promise Hall of Memories. Lagos: Oracle Books, 2001.

Okekwe, Promise Zita-Zita. Lagos: Oracle Books, 2002.

Okonjo Ogunyemi Chikwenye. Africa Wo/Man Palava -The Nigerian Novel by Women. Chicago: The University of Chicago Press, 1996.

Opara Chioma. (Ed.) Beyond the Marginal Land -Gender Perspectives in African Writing. PH, Nigeria: Beltop (Nig.), 1999.

Stratton Florence. Contemporary African Literature -The Politics of Gender. London: Routledge, 1994. 